\title{
YEAST ISOLATES TO INHIBIT BLUE MOULD AND BITTER ROT OF APPLES
}

\author{
K.S.H BOYD-WILSON ${ }^{1}$, N. GLITHERO ${ }^{2}$, Q. MA ${ }^{3}$, P. ALSPACH ${ }^{4}$ \\ and M. WALTER ${ }^{1}$ \\ ${ }^{1}$ HortResearch, P.O. Box 51, Lincoln, New Zealand \\ ${ }^{2}$ Christchurch Polytechnic, P.O. Box 540, Christchurch, New Zealand \\ ${ }^{3}$ College of Plant Protection, Northwest A\&F University, Yangling, \\ Shaanxi 712100, P.R. China \\ ${ }^{4}$ HortResearch, P.O. Box 220, Motueka, New Zealand
}

Corresponding author: kboyd-wilson@hortresearch.co.nz.

\begin{abstract}
Yeast isolates (44) collected from New Zealand orchards were screened for their ability to inhibit lesion development of blue mould of apples caused by Penicillium spp. and bitter rot of apples caused by Colletotrichum acutatum using a detached apple assay. While 28 isolates reduced blue mould lesions significantly compared to the pathogen control, only four of the 44 isolates reduced bitter rot lesion development significantly. These four yeast isolates also reduced the lesion development of blue mould. Increasing concentrations of selected yeasts decreased lesion size in a log-linear fashion. Yeasts applied before the pathogen reduced the lesion size significantly better than when applied after the pathogen. The best reduction in lesion development was achieved by live yeast cells, washed and applied in sterile water without any nutrient supplements. Yeast cell extracts did not result in reduced lesion development.
\end{abstract}

Keywords: Penicillium, Colletotrichum, apples, mode of action, restorative biological control.

\section{INTRODUCTION}

Blue mould of apples is caused by at least 11 species of Penicillium and is one of the most common postharvest diseases of pome fruit (Sutton 1997) with most infections occurring through wounds incurred during harvesting and handling. Due to the development of resistance to common fungicides and concerns with the effect of fungicides on the environment and human health (Eckert \& Ogawa 1988), the use of antagonists to control blue mould has been investigated (Castoria et al. 2001; Ippolito et al. 2000; Leibinger et al. 1997; Scherm et al. 2003). Currently, in the US there are at least three commercially available microbial antagonists on the market for the control of blue mould (Ippolito et al. 2000).

Colletotrichum acutatum is a pre and post-harvest disease of apples with quiescent infections occurring prior to harvest developing as the fruit ripens (Peres et al. 2005) causing typical bitter rot symptoms. The use of yeasts to control this disease has also been investigated (Suzzi et al. 1995).

Yeasts are readily found in the apple phyllosphere and, in a study on the impact of agrichemicals on microbial populations in New Zealand apple orchards, were found to make up over half of the RTU on an apple leaf (Waipara et al. 2002). The aim of this study was to determine for yeasts frequently found in New Zealand apple orchards their ability to suppress disease development of blue mould and bitter rot as a step towards restorative biological control (Everett et al. 2005). 
Isolates were selected from the eight main morphological yeast RTU as determined in earlier research (Bakker et al. 2002; Waipara et al. 2002). However, special emphasis was given to isolates of Aureobasidum pullulans (a yeast-like fungus henceforth referred to as a yeast), which is commonly found in New Zealand apple orchards (Pennycook \& Newhook 1981; Waipara et al. 2002), and is shown to suppress postharvest diseases (Castoria et al. 2001; Ippolito et al. 2000). A New Zealand isolate of Metchnikowia pulcherrima from the International Collection of Micro-organisms from Plants (ICMP), Manaaki Landcare Research, was also included in the tests as overseas isolates of this species have shown biological control potential against blue mould of apples (Janisiewicz et al. 2001).

\section{Pathogens}

\section{MATERIALS AND METHODS}

All pathogens were isolated from New Zealand apple orchards and stored at $-80^{\circ} \mathrm{C}$ in 30\% glycerol. Penicillium spp. isolates P1, P2 and P6 (sourced from P. Elmer, HortResearch) and Colletotrichum acutatum isolates C4, C7 and C8 (sourced from K. Everett, HortResearch), all from apple, were used in the experiments. These isolates were the most aggressive isolates based on lesion size on non-wounded and wounded, inoculated apples. Conidial suspensions for the apple assays were obtained by flooding 7- to 14-day old cultures growing on potato dextrose agar (PDA, Gibco) with sterile distilled water (SDW) and filtering through lens tissue. Unless otherwise stated, conidial concentrations were adjusted with the aid of a haemocytometer to $10^{7}$ and $10^{6}$ conidia $/ \mathrm{ml}$ respectively for Penicillium spp. and C. acutatum.

\section{Yeasts}

All yeasts, except one isolate of M. pulcherrima (ICMP 15535), were collected from New Zealand apple and apricot orchards from 2002 to 2005 and all were stored at $-80^{\circ} \mathrm{C}$ in $30 \%$ glycerol. Yeast cell suspensions were grown in nutrient yeast dextrose broth (NYDB) and prepared as described by Tian et al. (2002) except cells were washed in SDW.

\section{Apple assay}

The apple assay was adapted from Scherm et al. (2003). Briefly, cv. Braeburn apples (Malus domestica) were used in all experiments, except for two experiments where cv. Destaville was used due to the unavailability of cv. Braeburn. Apples were wiped with $100 \%$ ethanol and left to dry before wounding. Fruit were wounded at intervals around the shoulder to a depth of $4 \mathrm{~mm}$ with a sterile dissecting needle. There were four to eight wound sites per fruit depending on fruit size and number of treatments tested. Several yeasts were tested on the one fruit but each whole fruit was only challenged with one pathogen isolate. Each fruit also had a water control and pathogen only control wound site.

A $10 \mu \mathrm{l}$ aliquot of the yeast suspension was pipetted on to the wound site and allowed to dry at room temperature for up to $1 \mathrm{~h}$. Then a $10 \mu \mathrm{l}$ aliquot of the Penicillium spp. or C. acutatum isolate was pipetted onto the wound and allowed to dry at room temperature for up to $1 \mathrm{~h}$. Fruit (four to five) were randomised and placed in 2 litre plastic containers sealed with a fitted lid and incubated at $20^{\circ} \mathrm{C}$ in the dark. Lesion development was assessed after 5 and 10 days for the Penicillium and Colletotrichum isolates, respectively, by measuring the lesion diameter in two directions at right angles to each other. In all assays there were four to five apple replicates per treatment. This assay was used to determine the ability of 44 yeast isolates to inhibit blue mould (three isolates) and bitter rot (three isolates) of apples in five separate experiments. Yeasts were applied at $10^{8}$ colony forming units per $\mathrm{ml},(\mathrm{CFU} / \mathrm{ml})$.

From the results from these assays, yeast isolates that reduced lesion size to less than half of the pathogen control were chosen for studies on the effect of yeast concentration on pathogen suppression. Four yeasts at $10^{6}, 10^{7}$ and $10^{8} \mathrm{CFU} / \mathrm{ml}$ were screened against the three Penicillium isolates and a mix of equal proportions of the three Penicillium isolates on apple cv. Destaville. 
The effect of timing of yeast application was also investigated by applying these four yeasts before or after application of the pathogen. In this experiment, apples cv. Destaville were wounded at four sites per apple. Only the Penicillium mix was used in this experiment. Yeast or pathogen suspensions were sprayed until just before run-off on to the top of the apple with an air-brush (Badger) with up to $1 \mathrm{~h}$ drying time between the two applications. There was only one yeast treatment per fruit. Water and pathogen only control fruit were also included in the experiment. Apples were incubated and assessed as described above.

\section{Mode of action studies}

Mode of action of five A. pullulans isolates was studied by screening these on agar for antagonism towards the three Penicillium spp. and three $C$. acutatum isolates. Yeast cells from 4-day old cultures grown on malt extract agar (MEA, Merck) at $20^{\circ} \mathrm{C}$ were streaked onto PDA plates. Two yeast isolates were tested on each plate, with two replicate $4 \mathrm{~cm}$ streaks made on opposite sides of a plate. After 2 days growth at $20^{\circ} \mathrm{C}$ with a $12 \mathrm{~h}$ photoperiod, a plug $(6 \mathrm{~mm}$ diameter) of one of the pathogen isolates grown in the dark on PDA for 5 days was placed mycelial side down in the centre of the plate. Plates were incubated at $20^{\circ} \mathrm{C}$ in the dark and assessed every 2 days for up to 3 weeks, depending on how long the interaction between yeast and pathogen took to occur. The following key was used to assess this interaction:

$0=$ no inhibition of pathogen by yeast, pathogen grows over or under yeast

$1=$ no growth of pathogen on all or part of the yeast

2 = zone of no growth of pathogen around yeast

3 = zone of no growth and die-back of pathogen surrounding yeast

Using the apple assay, the mode of action was further studied for these five yeasts against the pathogens $\mathrm{C} 4, \mathrm{C} 8, \mathrm{P} 2$ and P6 by applying different yeast suspensions. The yeast suspensions were prepared as described above and the supernatant was collected after centrifuging to remove yeast cells. Treatments were:

A. The cell suspension prepared as described above (in SDW).

B. The yeast cells resuspended in fresh sterile NYDB.

C. The collected supernatant, autoclaved for 15 minutes at $121^{\circ} \mathrm{C}$.

D. The collected supernatant sterilised by filtering through a $0.2 \mu \mathrm{m}$ polycarbonate membrane filter (Millipore).

E. Sterile NYDB control (without yeast cells).

\section{Data analysis}

For all experiments, the geometric mean of the two lesion diameters (i.e. $\sqrt{d_{1} d_{2}}$ ) was the variate of interest. For the screenings on fruit, data were analysed using linear mixed effect modelling with pathogen and yeast as fixed effects, and experiment and fruit within experiment as random effects. This approach was also used for the concentration study with fruit as random effects, and yeast, pathogen and $\log _{10}$ concentration (linear and quadratic) as fixed effects. For the timing of application study, simple analysis of variance was used. These analyses were conducted using R 2.1.1 ( $\mathrm{R}$ Development Core Team 2005). The linear mixed effect models were fitted using lme() of the nlme library (Pinheiro \& Bates 2000). Split-plot analysis of variance, in GenStat 8.1, was used to analyse the data from the mode of action study.

\section{RESULTS}

Lesions on fruit were roughly elliptical and data are presented as the geometric mean of the major and minor axes. In all studies using the fruit assay, the water control was omitted from the analyses as there was no lesion development from this treatment. In the screening assay and mode of action study, no differences were found between pathogen isolates $(\mathrm{P}>0.05)$ and data for both rots are presented as a mean of the three isolates.

\section{Apple assays}

Of the 44 yeast isolates screened against the Penicillium isolates, 28 reduced lesion development significantly $(\mathrm{P}<0.05)$ compared to the pathogen only control. Twelve of the $14 \mathrm{~A}$. pullulans isolates screened were in this group. The remainder of the 28 isolates 
were from four of the eight RTU screened. Only four of the 44 yeast isolates reduced bitter rot lesion development significantly $(\mathrm{P}<0.05)$. These were four of the A. pullulans isolates that reduced lesion development of blue mould. The $M$. pulcherrima isolate did not reduce lesion development significantly $(\mathrm{P}>0.05)$.

In the analysis of the yeast concentration data, the pathogen only control with a yeast concentration of zero was excluded from the modeling as it was too far removed from the other concentrations to allow a good fit to be achieved using linear mixed effect modeling. In general, lesions resulting from the pathogen only treatments were smaller than those from the lowest yeast concentration, but larger than those from the higher yeast concentrations. Increasing yeast concentration decreased lesion size in a linear fashion (with respect to $\log _{10}$ concentration) for all yeasts and pathogens, but the decrease was more marked for $\mathrm{P} 2$ and $\mathrm{P} 6$ than for $\mathrm{P} 1$ or the mixture of these isolates.

Timing of yeast application affected the lesion size $(\mathrm{P}<0.05)$ with prior application of yeast resulting in smaller lesions than application after the pathogen (Table 1). All yeasts reduced lesion size significantly $(\mathrm{P}<0.05)$ compared with the pathogen only control.

TABLE 1 Mean lesion size (mm) for Penicillium isolates after five days when applied up to one hour after and before the yeast treatments.

\begin{tabular}{lcc}
\hline & Yeast first & Pathogen first \\
\hline Yeast 1 & 10.9 & 12.5 \\
Yeast 2 & 2.0 & 14.1 \\
Yeast 3 & 5.0 & 11.0 \\
Yeast 4 & 6.8 & 16.7 \\
Pathogen only & & 17.3 \\
LSD $(\mathrm{P}<0.05)$ & \multicolumn{2}{c}{5.2} \\
\hline
\end{tabular}

\section{Mode of action studies}

On agar, there was some evidence of inhibition of Penicillium spp. growth by all five A. pullulans isolates. This was seen as an area of no growth (score 1) of the Penicillium isolates on the yeast streak. The degree of this inhibition varied between Penicillium isolates and also within a plate and a within a streak on a plate. No antagonism was observed for any of the yeasts against the three Colletotrichum isolates.

Differences between the five A. pullulans isolates to inhibit blue mould and bitter rot were weaker ( $\mathrm{P}=0.036$ and 0.094 respectively) than differences among the suspension treatments. These were highly significant $(\mathrm{P}<0.001)$ for both pathogens. For Penicillium spp., yeast cells applied in SDW resulted in smaller $(\mathrm{P}<0.05)$ lesions than the pathogen control, but yeast cells resuspended in NYDB did not differ $(\mathrm{P}>0.05)$ from the pathogen only control. All other treatments resulted in larger lesions $(\mathrm{P}<0.05)$ than the pathogen only control. For $C$. acutatum, the treatments that significantly reduced lesion size $(\mathrm{P}<0.05)$ compared with the pathogen only control were yeast cells resuspended in SDW and NYDB (Table 2).

\section{DISCUSSION}

The apple assay allowed identification of yeasts that inhibited lesion development of blue mould and bitter rot in the laboratory. These yeast isolates were found in higher numbers and from a broader range of RTU for blue mould than for bitter rot, suggesting that this assay is more suited to a predominately wound infecting diseases such as blue mould. This inhibition was reproducible in the different experiments (screening, yeast cell concentration, timing of application and mode of action studies) using the apple assay.

The greatest reduction in lesion size was achieved when yeasts were applied before the pathogen. This is in agreement with the results of other researchers (Zhang et al. 2003; Zheng et al. 2005). The spray application technique gave control similar to the droplet 
TABLE 2: Mean lesion size ( $\mathrm{mm})$ following application of a range of yeast cell suspension treatments for Colletotrichum and Penicillium isolates.

\begin{tabular}{lcc}
\hline Suspension treatments & Colletotrichum $^{1}$ & Penicillium $^{1}$ \\
\hline A: cells in SDW & $5.04^{2}$ & $2.60^{3}$ \\
B: cells in fresh NYDB & 6.59 & 15.17 \\
C: supernatant autoclaved & 10.30 & 19.56 \\
D: supernatant filtered & 9.98 & 19.80 \\
E: NYDB & 9.52 & 19.88 \\
Pathogen control & 9.12 & 13.63 \\
LSD $(\mathrm{P}<0.05)$ & 1.01 & 2.11 \\
\hline
\end{tabular}

${ }^{1}$ After 10 and 5 days for Colletotrichum and Penicillium isolates, respectively.

${ }^{2}$ Numbers are the means of the five A. pullulans isolates.

${ }^{3}$ Omitted from the statistical analysis due to the high number of zero readings (total pathogen control).

inoculation. In experimentation that relies on natural infection rather than inoculation of the pathogen, this technique could be employed, as large numbers of fruit are often required to demonstrate treatment differences.

For both pathogens, increasing the concentration of the yeast cells improved lesion inhibition with the highest concentration of $10^{8} \mathrm{CFU} / \mathrm{ml}$ giving the greatest inhibition. This suggests that competition for nutrients and space is a factor in the mode of action of these yeasts. This may also explain the lack of inhibition at a yeast concentration of $10^{6} \mathrm{CFU} / \mathrm{ml}$.

Mechanisms of biocontrol by yeasts include the production of antibiotics and lytic enzymes, parasitism, induced resistance and/or competition for nutrients and space (Janisiewicz \& Korsten 2002). Although A. pullulans may produce the antibiotic aurebasidins (Janisiewicz \& Korsten 2002) there was no evidence of this as no significant inhibition was achieved for blue mould and bitter rot by either of the supernatant treatments. However, living yeast cells in SDW gave significant reduction in lesion size for both diseases. These results and the inhibition of growth of the Penicillium isolates on some parts of the yeast on agar plates, suggest that competition for nutrients and space plays a role in the biocontrol effectiveness of these yeasts for both diseases. This is in agreement with the findings of Castoria et al. (2001).

The yeast isolates did not suppress lesion development of blue mould in the presence of nutrients. In contrast, lesion size increased in all broth treatments compared with the pathogen only control. These trends were similar for bitter rot, although, treatment B (cells in NYDB), still reduced lesion size, albeit at a lower level than cells added in SDW. The reduced inhibition or even increase in lesion size in the presence of NYDB was probably due to the addition of nutrients at the wound site favouring the growth of the pathogen (Scherm et al. 2003).

Wound-invading fruit pathogens, such as blue mould, require nutrients for germination and infection (Janisiewicz \& Korsten 2002). Therefore, yeasts such as A. pullulans that compete for nutrients, readily multiply and grow on fruit-sugars, are good candidates for biocontrol on fruit.

Yeasts that are inhibitory to both Penicillium and Colletotrichum are common in New Zealand apple orchards. Manipulation of the orchard environment to stimulate growth and efficacy of these yeasts may be a possible new control strategy (Everett et al. 2005) and research in this area is currently being conducted. 


\section{ACKNOWLEGEMENTS}

Our thanks go to Philip Elmer, Mike Manning and Kerry Everett for providing their pathogen and yeast isolates and to Sam Boyd-Wilson for technical assistance. Also thanks to the New Zealand Foundation for Research, Science and Technology for funding this project (C06X0302) and to Frances Well and the Christchurch Polytechnic for financial support via a student placement.

\section{REFERENCES}

Bakker GR, Frampton CM, Jaspers MV, Stewart A, Walter M 2002. Assessment of phylloplane microorganism populations in Canterbury apple orchards. New Zealand Plant Protection 55: 129-134.

Castoria R, De Curtis F, Limi G, Caputo L, Pacifico S, De Cicco V 2001. Aureobasidium pullulans (LS-30) an antagonist of postharvest pathogens of fruits: study on its modes of action. Postharvest Biology and Technology 22 (1): 7-17.

Eckert JW, Ogawa JM 1988. The chemical control of postharvest diseases: deciduous fruits, berries, vegetables and root/tuber crops. Annual Review of Phytopathology 26: 433-469.

Everett KR, Vanneste JL, Hallett IC, Walter M 2005. Ecological alternatives for disease management of fruit rot pathogens. New Zealand Plant Protection 58:55-61.

Ippolito A, El Ghaouth A, Wilson CL, Wisniewski M 2000. Control of postharvest decay of apple fruit by Aureobasidium pullulans and induction of defense responses. Postharvest Biology and Technology 19 (3): 265-272.

Janisiewicz WJ, Korsten L 2002. Biological control of postharvest diseases of fruits. Annual Review of Phytopathology 40: 411-441.

Janisiewicz WJ, Tworkoski TJ, Kurtzman CP 2001. Biocontrol potential of Metchnikowia pulcherrima strains against blue mold of apple. Phytopathology 91 (11): 1098-1108.

Leibinger W, Breuker B, Hahn M, Mendgen K 1997. Control of postharvest pathogens and colonization of the apple surface by antagonistic microorganisms in the field. Phytopathology 87 (11): 1103-1110.

Pennycook SR, Newhook FJ 1981. Seasonal changes in apple phylloplane microflora. New Zealand Journal of Botany 19: 273-283.

Peres NA, Timmer LW, Adaskaveg JE, Correll JC 2005. Lifestyles of Colletotrichum acutatum. Plant Disease 89 (8): 784-796.

Pinheiro JC, Bates DM 2000. Mixed-effects Models in S and S-Plus. Springer-Verlag Inc., New York, USA. 528 pp.

Scherm B, Ortu G, Muzzu A, Budroni M, Arras G, Migheli Q 2003. Biocontrol activity of antagonistic yeasts against Penicillium expansum on apple. Journal of Plant Pathology 85 (3): 205-213.

Sutton TB 1997. Bitter rot. In: Jones AL, Aldwinckle HS ed. Compendium of apple and pear diseases. APS Press, USA. p. 16.

Suzzi G, Romano P, Ponti I, Montuschi C 1995. Natural wine yeasts as biocontrol agents. Journal of Applied Bacteriology 78 (3): 304-308.

Tian S, Fan Q, Xu Y, Liu H 2002. Biocontrol efficacy of antagonist yeasts to gray mold and blue mold on apples and pears in controlled atmospheres. Plant Disease 86 (8): 848-853.

Waipara NW, Obanor FO, Walter M 2002. Impact of phylloplane management on microbial populations. New Zealand Plant Protection 55: 125-128.

Zhang H, Zheng X, Xi Y 2003. Biocontrol of postharvest blue mould rot of pear by Cryptococcus laurentii. Journal of Horticultural Science and Biotechnology 78 (6): 888-893.

Zheng X, Zhang H, Sun P 2005. Biological control of postharvest green mold decay of oranges by Rhodotorula glutinis. European Food Research and Technology 220: 353-357. 